\title{
ISLAMISASI DAN SYARIATISASI SAMUDERA-PASAI ABAD KE-14 MASEHI
}

\author{
Ayang Utriza Yakin \\ Universitas Islam Negeri Syarif Hidayatullah Jakarta, Indonesia \\ E-mail: ayang.utriza@uinjkt.ac.id
}

\begin{abstract}
This article discusses the process of Islamization and shariahization in Samudera Pasai. Pasai was the first region to be islamized by those who spread Islam from Arabian peninsula. From this region Islam spread throughout Nusantara. Pasai played an important role in Islamizing Nusantara. Based on local and foreign sources as well as the historiography of Pasai, this article tries to elaborate the process of Islamization of Samudera Pasai comprehensively. In terms of shariahization, it is meant as an endeavor to implement Islamic law which was initially identical with Islamization. Based on Ibn Baṭ̂țah, a Moroccon traveller, who visited Pasai, it is apparent that some aspects of Islamic law had been implemented and constituted as an integral part of societal and political life in this Muslim kingdom. This article shows that Islamic law had been practiced from the beginning as it went hand in hand with the process of Islamization.
\end{abstract}

Keywords: Aceh; Samudera Pasai; sultan; qâdị (judge); faqîh (jurist).

\section{Pendahuluan}

Samudera-Pasai, di Timur Laut Sumatera, terletak di antara dua sungai besar: Peusangan dan Pasai. Di selatan, ia memanjang hingga sungai Jambu Aye di perbatasan Perlak, dan di Utara hingga Semerlangga. ${ }^{1}$ Samudera-Pasai terletak di pinggir laut Lhokseumawe, dan karenanya dekat dengan selat Malaka.

\footnotetext{
1 A.H. Hill, "Hikayat Raja-raja Pasai", Journal of the Malayan Branch Royal Asiatic Society, XXXIII, No 2 (1960), 10-12. Hasan Muarif Ambary, Menemukan Peradaban: Arkeologi dan Islam di Indonesia, sunt. Jajat Burhanuddin (Jakarta: Puslit Arkenas, 1998), 128. Sekarang, Samudera-Pasai merupakan bagian dari kecamatan Samudera Kabupaten Aceh Utara, Provinsi Nangroe Aceh Darussalam (NAD).
} 
Selat Malaka digunakan bagi perdagangan internasional melalui laut yang menghubungkan Laut Merah dan Cina. Pertumbuhan pelabuhan-pelabuhan besar sepanjang selat Malaka dan Samudera Hindia telah membuat laut menjadi jalur terpenting untuk aktivitas ekonomi di Nusantara. Selat Malaka berubah menjadi "Jalur Sutera" yang menghubungkan pedagang dari Barat yang datang dari Persia, Arab, dan India menuju ke Cina. ${ }^{2}$

Penemuan arkeologi di Samudera-Pasai menunjukkan bahwa kota itu adalah satu pelabuhan sangat tua dalam persimpangan perdagangan internasional. ${ }^{3}$ Menurut satu sumber Cina, pada abad ke VI dan VII, hubungan perdagangan telah terjalin antara Nusantara dengan Persia, Arab dan Cina. ${ }^{4}$ Selanjutnya, hubungan perdagangan ini berkembang berkat dua imperium besar: di Barat ada Khilafah Umayyah (661-750) dan Khilafah 'Abbasîyah (750-1258), dan di Timur terdapat Kekaisaran Tang (618-907) dan Kekaisaran Sung (960-1280). ${ }^{5}$ Sepanjang masa Umayyah, perjalanan menuju ke Cina dilakukan lewat darat. Tetapi, karena ada perang antara umat Islam, Cina, dan salah satu suku Tibet menyebabkan terputusnya jalur darat. $\mathrm{Hal}$ ini menyebabkan turunnya aktivitas perdagangan dan peningkatan perjalanan lewat laut. Hubungan perdagangan antara Barat dan Timur meningkat pada masa 'Abbasiyah.

Perdagangan jalur laut harus melewati kepulauan Nusantara bagi yang hendak pergi ke Cina. Pada masa itu, di kepulauan Nusantara, kerajaan Sriwijaya di Sumatra menguasai sebagian besar daerah-daerah di bagian Barat Nusantara. ${ }^{7}$ Ibu kota Sriwijaya, terletak dekat Palembang, menjadi salah satu pelabuhan yang dikunjungi oleh

\footnotetext{
${ }^{2}$ Hasan Muarif Ambary, "Peranan Beberapa Bandar Utama di Sumatera Abad 7-16 M. dalam Jalur Sutera Melalui Lautan", Kalpataru Majalah Arkeologi, edisi Saraswati Esai-Esai Arkeologi, No. IX, 1990, 61.

${ }^{3}$ Ibid., 128-131.

${ }^{4}$ Lihat pendahuluan dari Hirth dan Rockhill dalam Chau-Ju-Kua, Chau Ju-Kua: His Work on the Chinese and Arab Trade in the Twelfth and Thirteenth Centuries, entitled ChuFan-Chi, terj. Friedrich Hirth dan W. W. Rockhill (St. Petersburg: The Imperial Academy of Sciences, 1911), 9.

5 Marshall Broomhall, Islam in China: a Neglected Problem (London: Morgan \& Scott ltd., 1905), lihat secara khusus bab I dan II, 5-36.

" G.R. Tibbets, "Early Muslim Traders in South-East Asia", Journal of the Malayan Branch Royal Asiatic Society, XXX, No. 1 (1957), 5.

7 G. Coedès, Les Etats Hindouisés d'Indochine et d'Indonésie (Paris: De Boccard, 1989). Lihat juga G. Ferrand, L'empire Sumatranais de Sriwijaya (Paris: Journal Asiatique, 1922).
} 
pedagang-pedagang Arab. ${ }^{8}$ Oleh karena itu, salah satu di antara pedagang Arab ini menjadi salah satu 'pimpinan' di Sriwijaya pada tahun 55 H./674 M. ${ }^{9}$ Namun, kita tidak mengetahui apakah pedagang Arab itu seorang Muslim atau bukan.

Pada abad VIII-IX, para pedagang Muslim-Arab telah pergi berdagang ke kepulauan Nusantara. ${ }^{10}$ Penegasan yang paling jelas mengenai hubungan perdagangan antara Arab dan Nusantara diberikan oleh sumber-sumber Arab, seperti: Akbbâr al-Sin wa alHind $^{11}$, Silsilat al-Tawârîh karangan Sulaymân al-Sirâfî (IX) ${ }^{12}$ dan alBuldân karangan Ibn al-Faqîh al-Hamâdânî (289-290/902-903). ${ }^{13}$ Di dalam sumber-sumber Arab ini ditulis bahwa seorang pedagang Arab, bernama Sulaymân, pergi ke kepulauan Nusantara: Lambri, Fansur, Zabej dan Kalah-Bar untuk berdagang. ${ }^{14}$

Tulisan pelancong Arab yang lain adalah 'Aghâib al-Hind Barrib wa Bahrih wa Ghazâirih dari Buzurgh b. Syahriyâr al-Ramhurmûzi yang berasal dari abad X (390/1000). Ia menginformasikan keberadaan

8 Tibbets, "Early Muslim Traders", 3.

9 W. P. Groeneveldt, "Notes on The Malay Archipelago and Malacca Compiled Form Chinese Sources", Verhandelingen Van Het Bataviaasch Genootschap Van Kunsten En Wetenschappen, XXXIX, No. 1 (1877), 14. Lihat juga Syed Muhammad Naguib alAttas, Preliminary Statement on a General Theory of the Islamization of the Malay-Indonesian Archipelago (Malaysia: Dewan Bahasa dan Pustaka, 1969), 11; dan Tibbets, "Early Muslim Traders", 37-38.

${ }_{10}$ G.R. Tibbets, "Pre-Islamic Arabia and South-East Asia", Journal of the Malayan Branch Royal Asiatic Society, XXIX, No. 3 (1956), 207.

11 Jean Sauvaget (ed.), Akbbâr al-Sîn wa al-Hind, Relation de la Chine et de l'Inde, Les Belles Lettres (Paris: Société, 1948), 4, 8. Buku yang disunting oleh Sauvaget terdiri dari dua manuskrip. Ia menyatakan bahwa penulis buku pertama tidak diketahui, sementara penulis buku kedua adalah Abû Zayd al-Sirâfî.

12 Sulaymân al-Sirâfî, Silsilat al-Tawârîh dan "Relations des Voyages Faits par les Arabes et les Persans dans l'Inde et à la Chine dans le IXème Siècle de l'Ere Chrétienne", Joseph Touissant Reinaud (ed.), Vol. 2 (Paris: O. Zeller Verlag \& Osnabrück Allemagne, 1982), 89-101.

13 Ibn al-Faqîh al-Hamadânî, al-Buldân, Abrégé du Livre des Pays, terj. Henri Masse (Damaskus: Institut Francais de Damas, 1973), 13-15.

${ }^{14}$ Lambri terletak di Barat Laut Sumatra dekat dengan Aceh, Fansur adalan daerah di pinggir pantai Selatan Sumatra, sekitar Barus, pusat ekspor kamper ke Timur Tengah. Lihat Sauvaget, Akhbâr al-Sîn, 37. Sauvaget telah melakukan kesalahan, karena Barus tidak terletak di pantai Selatan, tetapi di pantai Utara Sumatra. Adapun Zabaj, orang mengira bahwa Zabaj terletak di sekitar Sumatra (Sriwijaya). Lihat R.O. Winstedt, "A History of Malaya", Journal of The Malayan Branch Royal Asiatic Society, Vol. XIII, No. 1 (1935), 23; Ibn Sahriyâr, Kitâb Aghâib al-Hind Barrih wa Babrih wa Ghazâirih (288-342 H.), P. A. Van Der Lith (ed.) (Leiden: E.J. Brill, 1883-1886), 231. 
komunitas Muslim di kerajaan Zabedj (Sriwijaya) di Sumatra. ${ }^{15}$ Pada abad XII, Chau Ju-Kua, mempertegas bahwa banyak penduduk SanFo-T'si (Palembang/Sriwijaya) dinamai dengan "P'u." Hirth dan Rockhill menjelaskan bahwa P'u adalah kependekan dari bahasa Arab: Abu, yang bermakna Bapak. ${ }^{16}$ Namun demikian, hal ini bukanlah satu kepastian, karena di Jawa ada orang yang bernama P'u yang tidak ada kaitannya dengan bahasa Arab. ${ }^{17}$

Pada tahun 1258, terjadi krisis politik di Timur Tengah, yaitu hancurnya Khilafah 'Abbasiyah akibat serangan bangsa Mongol. Kejatuhan Baghdad telah merubah jalur perdagangan yang sebelumnya pergi dari Teluk Persia melalui Baghdad ke pelabuhan Syiria dan Asia Kecil. Sekarang, jalur itu melewati Aden dan Mocha (Yaman), Jeddah, Laut Merah via Iskandarîyah (Mesir), sampai Eropa melalui Italia. ${ }^{18}$ Jalur itu menyatukan jalur ke Timur menuju Cina melalui India dan kepulauan Nusantara.

Setelah kejatuhan Baghdad, perdagangan dilakukan secara besarbesaran dengan Mesir. Di sisi lain, Jeddah menjadi pelabuhan persinggahan untuk para pedagang India. Mereka memiliki hubungan dengan Mesir, sementara Jeddah dan Yaman adalah penyalur untuk pasar-pasar di Eropa. ${ }^{19}$ Perubahan jalur perdagangan tersebut merupakan awal kesejahteraan khilafah Mamlûk di Mesir (1250-1517). Bahkan, sejak abad ke-10, pada masa dinasti Fâțimîyah (969-1174), Kairo sudah menjadi pusat perdagangan produk-produk yang berasal dari Timur. ${ }^{20}$ Jatuhnya Baghdad semakin memperkuat hak istimewa Kairo sebagai pusat perdagangan.

Pada saat yang sama, Samudera-Pasai telah mengakui kedaulatan kekaisaran Cina. Kemerdekaan kerajaan Samudera-Pasai ditegaskan oleh sumber-sumber Cina yang menjelaskan bahwa pada 1275, kaisar Cina tidak lagi menerima sesembahan dari raja San-Fo-Tsi (Sriwijaya),

\footnotetext{
${ }^{15}$ Ibn Sahriyâr, Kitâb Aghâib, 154.

${ }^{16}$ Chau Ju-Kau, Chan Ju-Kua: His Work on the Chinese and Arab Trade in the Twelfth and Thirteenth Centuries, Entitled Chu-fanchi (New York: Paragon Book Reprint Corp, 1966), 60-65.

17 Sebagai contoh, Mpu Tantular, Mpu Gandring dan pengarang Negarakertagama Mpu Prapanca. Adalah sangat penting diungkapkan di sini bahwa Mpu berasal dari Pu yang mana orang Jawa menambahkan hurup "M" di depannya. Karena itu, Pu di sini bukan bahasa Arab. Claude Guillot, Wawancara, Paris, 25 Mei 2004.

18 B. Schrieke, Indonesian Sociological Studies, Vol. 2 (The Hague and Bandung: Van Hoeve, 1955 dan 1957), 233.

${ }^{19}$ Ibid., Vol. 1, 9.

20 Tibbets, "Early Muslim Traders”, 23, 43.
} 
tetapi dari raja Sa-Wen-Ta-La (Samudera). ${ }^{21}$ Pada 1292, Marco Polo melaporkan bahwa kerajan Samara (Sumatera) dan kerajaan Basman mengakui kedaulatan Kubilai Khan yang Agung:

Mereka (penduduk Samara) mengakui kedaulatan (Kubilai) Khan yang Agung, tetapi mereka sama sekali tidak membayar upeti, karena mereka sangat jauh hingga orang-orang Khan yang Agung tidak dapat pergi ke sana". ... "Mereka (penduduk Basman) juga mengakui Khan yang Agung. ${ }^{22}$

Perluasan kekuasan politik dan ekonomi kekaisaran Cina memperkuat keberadaan Islam di Sumatera. Pada saat yang bersamaan, terjadi perubahan keadaan politik di Timur-Tengah pada abad ke- 13 yang telah mendorong penyebaran umat Islam, terutama para sufi. Menurut A.H. Johns para sufi dan pedagang bekerja sama untuk menyebarkan agama Islam. ${ }^{23}$ Marco Polo menegaskan bahwa para pedagang Muslim telah mengislamkan, misalnya, Kerajaan Perlak:

Kami ceritakan pertama-tama mengenai Kerajaan Perlak.... Ketahuilah bahwa dahulu kala orang-orang ini menyembah berhala, namun karena para pedagang Muslim yang sering mengunjungi mereka dengan perahu, semua orang-orang itu berpindah agama yang mengerikan: agama Muhammad. ${ }^{24}$

Hal tersebut menunjukkan bahwa aktivitas ekonomi memainkan perang penting dalam kedatangan Islam di Nusantara. ${ }^{25}$ Kita dapat menyimpulkan bahwa dari abad ke-8 sampai abad ke-12, agama Islam telah diperkenalkan di Nusantara oleh para pedagang Muslim.

\footnotetext{
21 Ambary, Menemukan Peradaban, 59-60.

22 Marco Polo, Le Devisement Du Monde Le Livre Des Merveilles 1250-1295, disunting oleh A.C. Moule, Louis Hambis dan Stéphane Yerasimos, Vol. 2 (Paris: La Découverte, 1989), 413, 415.

23 A.H. Johns, "Sufism as a Category in Indonesian Literature and History", Journal Southeast Asian History, Vol. 2, No. 2 (1961), 13-14.

${ }^{24}$ Polo, Le Devisement Du Monde, 413. Lihat juga Marco Polo, Le Livre de Marco Polo, disunting oleh M.G. Pauthier (Paris: Firmin Didot Frères, 1865), 568-569.

25 G.W.J., Drewes, "New Light on the Coming of Islam to Indonesia", The Propagation of Islam in the Indonesian-Malay Archipelago, Alijah Gordon (ed.) (Kuala Lumpur: Malaysian Sociological Research Institute, 2001), 129; B.H.M. Vlekke, Nusantara a History of Indonesia (The Hague dan Bandung: Van Hoeve, 1943), 80 dan 83; M.C. Ricklefs, A History of Modern Indonesia (London: The Macmillan Press, 1981), 3; Uka Tjandrasasmita, "The Sea Trade of the Moslems to the East Countries and the Rise of Islam in Indonesia", Makalah pada Asian History Congress, Azad Bhaven, New Delhi, 1961, 3-4.
} 
Perlahan-lahan, mereka membuat satu kelompok kecil masyarakat Muslim berkat pernikahan dan dakwah. Kelompok masyarakat itu lambat laun bertambah penting dan menjadi masyarakat Muslim. Inilah yang menjadi alasan mengapa masyarakat Islam baru muncul pada abad ke-13 di Kerajaan Perlak.

\section{Keislaman Samudera-Pasai}

Sebelum memeluk agama Islam, budaya dan tradisi SamuderaPasai telah dipengaruhi oleh agama Budha dan Hindu. Selama masa kerajaan Sriwijaya, agama Budha berkembang di samping agama Hindu. ${ }^{26}$ Menurut pengelana Cina abad ke-7, I-Tsing, bahwa kerajaan Sriwijaya adalah pusat belajar agama Budha. ${ }^{27}$ Animisme juga masih hidup di samping agama Budha dan Hindu. ${ }^{28}$ Itulah mengapa pada 1292, Marco Polo melaporkan bahwa Basman dan Samara (Sumatra) masih dihuni oleh para penyembah berhala. ${ }^{29}$

Kendati demikian, corak makam tertanggal akhir abad ke-13 yang ditemukan di Pasai menyebutkan bahwa Malik al-Saleh adalah sultan pertama kerajaan Samudera-Pasai meninggal pada $1297 .{ }^{30}$ Kita dapat menduga bahwa Islam menyebar dengan cepat dari Perlak ke Samudera-Pasai Samudera-Pasai antara 1292 dan 1297. ${ }^{31}$ Kita mengetahui bahwa menurut sumber-sumber Cina, dua utusan Muslim, Husain dan Sulaiman, datang dari Su-Mu-Ta-La (Samudera) mengunjungi Cina pada 1282. ${ }^{32}$ Setahun sebelumnya, pada 1281, Malayu (Samudera-Pasai) telah mengirimkan dua utusan Muslim, Sulaymân dan Syamsuddin ke Cina. ${ }^{33}$ Ini alasan mengapa De Jong menduga bahwa kerajaan Islam Samudera-Pasai didirikan sebelum pengirim dua utusan ke Cina dan kunjungan Marco Polo. ${ }^{34}$ Demikian

\footnotetext{
26 Tim Penulis, Sejarah Daerah Propinsi Daerah Istimewa Aceh Jakarta: Balai Pustaka, 1977-1978), 51.

${ }^{27}$ I-Tsing, A Record of the Buddhist Religion as Practised in India and the Malay Archipelago: A.D. 671-695, terj. J. Takakusu (London, Oxford University Press, 1896), 10.

28 Tim Penulis, Sejarah, 51.

${ }^{29}$ Polo, Le Devisement Du Monde, 413 dan 415.

30 Louis-Charles Damais, "L'épigraphie Musulmane dans Le Sud-est Asiatique", Bulletin de l'Ecole Française d'Extrême Orient, Vol. LIV (1968), 579.

31 Arun Kumar Das Gupta, "Acheh in Indonesian Trade and Politics 1600-1641" (Disertasi--Universitas Cornell, 1962), 10.

32 Schrieke, Indonesian Sociological Studies, Vol. 2, 255; Hill, "Hikayat Raja-raja Pasai", 8; dan Drewes, "New Light on the Coming of Islam to Indonesia", 137.

${ }^{33}$ Winstedt, "The Chronicles of Pasai", 29.

${ }^{34}$ S. Q. Fatimi, Islam Comes to Malaysia (Singapore: Malaysian Sociological Research Institute, 1963), 10.
} 
juga bagi E. Gerini yang mengira bahwa Samudra telah diislamkan antara $1270-1275 .{ }^{35}$ Mulyana lebih jauh mengatakan bahwa kesultanan Pasai telah didirikan oleh Nizâm al-Dîn al-Kâmil, kepala angkatan laut Khilafah Fâtimîah di Mesir pada 1128 untuk menguasai perdagangan lada di pantai Timur Sumatra. ${ }^{36}$ Tetapi, ia tidak memberikan satu pun bukti untuk menegaskan hipotesanya.

Terkait dengan masuknya kekuasaan Samudera-Pasai ke dalam agama Islam, kita menduga bahwa raja Samudera-Pasai, Malik alSaleh, memeluk agama Islam melalui pernikahannya dengan puteri sultan Perlak. ${ }^{37}$ Adapun menurut Hikayat Raja-raja Pasai, ${ }^{38}$ raja Merah Silu kemungkinan masuk agama Islam setelah bermimpi bertemu dengan Rasulullah. Dalam mimpi itu, Nabi Muhammad menyuruh raja Merah Silu mengucapkan dua kalimat syahadat. ${ }^{39}$ Nabi meludah ke dalam mulut Merah Silu agar bisa mengucapkan syahadat. Kemudian, Rasulullah memberikan nama Islam, Malik al-Saleh. Raja ini dapat membaca al-Qur'ân dengan benar hingga akhir tanpa lebih dahulu belajar. Menurut cerita lain, Samudera ini diislamkan oleh seorang Shaykh Ismâil langsung datang dari Makkah berdasarkan perintah Sharîf Makkah yang mengingatkan tentang hadîth Rasulullah untuk pergi mengislamkan Samudera. Saat itu, para Sharîf Makkah berada di bawah kekuasaan Mesir. ${ }^{40}$

Shaykh Ismâil bertemu Malik al-Saleh dan menyuruhnya mengucapkan dua kalimat syahadat. Keesokan harinya, Shaykh Ismâil dan seorang fakir meminta raja membaca al-Qur'ân. Ia dapat membaca al-Qur'ân seluruhnya tanpa seorang pun pernah mengajarinya sebelumnya. Sedikti berbeda, kejadian ini juga diceritakan oleh Sulâlat al-Salaṭ̂n yang menegaskan bahwa Merah Silu telah diislamkan oleh seorang fakir, yaitu Shaykh Ismâill, dan juga

35 Teuku Ibrahim Alfian, Kronika Pasai: Sebuah Tinjanan Sejarah (Yogyakarta: Gadjah Mada University Press, 1973), 20.

36 Slamet Mulyana, Runtubnya Keradjaan Hindu-Djawa dan Timbulnya Negara-negara Islam di Nusantara (Jakarta: Bharata, 1968), 134.

${ }^{37}$ Polo, Le Livre de Marco Polo. Lihat catatan pada 569.

38 Russel Jones (penyunting), Hikayat Raja-raja Pasai (Kuala Lumpur: Fajar Bakti, 1987), 12-16. Lihat juga Hill, "Hikayat Raja-raja Pasai", 55-59. Alfian, Kronika Pasai, 48-52.

39 Mengucapkan Ashhad an lâ ilâh illâ Allâh wa ashhad anna Muhammad rasûl Allâh (Saya bersaksi tidak ada tuhan selain Allah dan aku bersaksi bahwa Muhammad adalah utusan Allah).

${ }^{40}$ Hervé Bleuchot, Droit Musulman, Vol. 1 (Aix-en-Provence: Presses Universitaires d'Aix Marseille, 2002), 166. 
setelah bertemu Rasulullah di dalam mimpinya. Selanjutnya, setelah raja Samudera-Pasai masuk Islam, maka semua para pembesar kerajaan dan penduduknya masuk Islam juga.

Setelah memeluk agama Islam, Sultan Malik al-Saleh belum menikah. Para menteri dan hulubalang membicarakan perihal puteri Sultan Perlak. Tidak lama setelah itu, Malik al-Saleh menikahi Puteri Ganggang Sari (Putri Raihani), salah satu dari tiga puteri Sultan Perlak Makhdum Alauddin Malik Muhammad Amin Syah II Johan Berdaulat. ${ }^{41}$ Pernikahan ini patut diduga dilaksanakan sesuai dengan hukum Islam, karena Perlak sudah menjadi Islam, sebagaimana diberitakan oleh Marco Polo saat ia berkunjung ke Sumatra pada 1292. Adapun sumber lokal Sulâlat al-Salatinn menyebutkan bahwa Perlak telah diislamkan, sebelum Samudera-Pasai, oleh Shaykh Ismâil dan seorang fakir. ${ }^{42}$

Masa kebesaran kesultanan Samudera-Pasai terjadi pada abad ke14. Kesultanan Perlak disatukan dengan kesultanan Samudera-Pasai pada masa Malik al-Zahirr ${ }^{43}$ pada awal abad yang sama. Saat penyatuan itu, diceritakan di dalam Sulâlat al-Salatîn, para penduduk Perlak melarikan diri setelah kekalahan kerajaan mereka, lalu pergi ke Samudera. ${ }^{44}$ Saat itu, Kesultanan Samudera-Pasai memiliki seorang bendabara agung, bernama Orang Kaya Raja Kenayan ${ }^{45}$ yang bekerja dengan Sultan untuk memperluas wilayah kerajaan. Selain itu, kekuatan Samudera-Pasai bergantung pada, di satu sisi, tempat strategis yang dimilikinya, suatu pelabuhan penting untuk pergi menuju ke Cina, dan si sisi lain, kesuburan tanahnya. ${ }^{46}$ Wilayah kesultanan berada di sepanjang sungai hingga dataran tinggi pedalaman, Gayo, Aceh Tengah, dan di sebelah pegunungan Peut Sagoe. Kemakmuran dan kekayaan Samudera-Pasai diberitakan oleh

41 Muhammad Ibrahim dan Rusdi Sufi, "Sekelumit Pendapat tentang Proses Islamisasi dan Munculnya Kerajaan-kerajaan Islam di Aceh", makalah yang disajikan pada Seminar Sejarah Masuk dan Berkembangnya Islam di Aceh dan Nusantara, Aceh Timur, 25-30 September 1980, 17. Lihat juga Alfian, Kronika Pasai, 53-55.

42 Tun Seri Lanang, Sulalat al-Salatîn Ya'ni Pertuturan Segala Raja-raja: Sejarah Melayu, Muhammad Haji Salleh (ed.) (Kuala Lumpur: Dewan Bahasa dan Pustaka, 1997), 38.

${ }^{43}$ Ibrahim dan Sufi, "Sekelumit Pendapat tentang Proses Islamisasi”, 17.

${ }^{44}$ Lanang, Sulâlat al-Salatîn, 39.

45 Ibid, 66.

46 Muhammad Gade Ismail, Pasai dalam Perjalanan Sejarab: Abad ke-13 Sampai Awal Abad ke-16, Jakarta: Departemen Pendidikan dan Kebudayaan, 1993, 6. 
Odoric de Pordenone, seorang pendeta Fransiskan, yang mengunjungi kesultanan ini. Bahkan, ia menulis beberapa kekayaan sumber daya alam daerah tersebut, seperti beras, emas, tembaga dan juga binatang-binatang. ${ }^{47}$ Panen padi dilakukan dua kali dalam setahun di daerah dataran rendah sepanjang abad ke-14. Hasil hutan seperti kayu dan lada membuat masyarakat bertambah makmur. ${ }^{48}$ Lada merupakan hasil utama Samudera-Pasai. ${ }^{49}$ Hasil lada ini membuat kesultanan berkembang, tetapi pada saat yang sama menimbulkan kecemburuan kerajaan-kerajaan tetangga. Samudera-Pasai diserang dua kali karena alasan ekonomi dan politik sekaligus. Mereka yang menyerang Samudera-Pasai adalah kerajaan-kerajaan pertanian yang memiliki wilayah yang luas dan penduduk yang banyak. Selain itu, Samudera-Pasai adalah kerajaan maritim.

Kemakmuran Samudera-Pasai terjaga hingga sultan yang terakhir Sultan Zain al-'Abidin (1513-1524). Mengenai hal ini, Tomé Pires, seorang pengelana Portugis, menyatakan saat perjalanannya di Nusantara pada awal abad ke-16 bahwa kesultanan Samudera-Pasai adalah kerajaan yang kaya dan sejahtera. Terdapat 20.000 penduduk di Pasai. Hasil bumi yang paling penting dari Samudera-Pasai adalah lada, sutera dan kapur barus. Tiap tahunnya, Samudera-Pasai memroduksi 8 hingga 10 bahar lada. Di antara banyak pedagang dari negara berbeda, Tome Pires melihat banyak pedang Muslim di Pasai. Mereka adalah orang Rumi ${ }^{50}$ (penduduk Konstantinopel di bawah kekuasaan Turki-Usmani), Turki, Arab, Persia, Gujarat, Keling, Jawa, Siam-Kedah, Pegu dan Beruas. Akan tetapi, yang paling banyak adalah orang-orang Benggali. Catatan Pires mengenai Pasai sangat kaya yang mengizinkan kita melihat bahwa Samudera-Pasai pada abad ke-16 adalah suatu pelabuhan perdagangan internasional yang penting, sebagaimana Odoric de Pordenone mempertegasnya pada abad ke$14 .{ }^{51}$

${ }^{47}$ L. Bressan, "Odoric of Pordenone (1265-1331): His Vision of China and SouthEast Asia and His Contribution to Relations between Asia and Europe", Journal of the Malayan Branch Royal Asiatic Society, LXX, No 2, 1997, 18.

48 Ibid., 8

49 M.A.P. Meilink-Roeflofsz, Asian Trade and European Influence in the Indonesian Archipelago between 1500 and About 1630 (The Hague: M. Nijhoff, 1962), 19

${ }^{50}$ Orang-orang yang tinggal di Konstantinopel di bawah Kekaisaran Turki-Usmani.

51 Tomé Pires, The Suma Oriental Of Tome Pirés, An Account Of The East From The Red Sea To Japan, Written In Malacca And India In 1512-1515, Vol. 1 (New Delhi: Asian Educational Services, 1990), 142-144. 
Jadi, kita tahu bahwa kemakmuran Samudera-Pasai menarik para pedagang dari bermacam negara. Di antara mereka terdapat pedagang Muslim dan di antaranya terdapat para pendakwah professional, seperti para sufi, yang menyebarkan Islam. Arus kedatangan kaum Muslimin di Nusantara dapat dijelaskan sebagian akibat krisis politik di Timur-Tengah. Kedatangan Islam bersamaan juga dengan pengaruh politik Cina di Nusantara. Sedikit demi sedikit, politik menjadi jalan penyebaran agama Islam. ${ }^{52}$ Pada saat itulah, Samudera-Pasai memeluk agama Islam.

\section{Islam dan Hukum Islam}

Kemunculan bentuk baru kekuasaan pada akhir abad ke-13 di Samudera-Pasai, yaitu kesultanan, telah merubah secara mendalam sistem politik yang telah dikenal hingga saat itu di kepulauan Nusantara. ${ }^{53}$ Setelah perpindahan agama baru oleh raja dan penduduknya, Islam memainkan peran penting. Samudera-Pasai secara perlahan menjadi pusat keislaman yang sangat dinamis. Bahkan, ia telah menjadi pusat dan inti dari penyebaran agama baru itu. Dari sejak itu, agama Islam menyebar secara cepat di Sumatera, Semenanjung Melayu, di Jawa, Maluku dan di daerah-daerah lain di Nusantara. Kekuasaan politik menjadi gema agama Islam. Dengan demikian, Samudera-Pasai telah menjadi pusat penyebaran agama Islam. Perubahan sistem politik Samudera-Pasai yang menjadi islami mendorong penggantian sistem hukum. Pertanyaannya kemudian “jenis hukum apakah yang penguasa tetap pertahankan".

Kita mengetahui tentang Islam dan penerapan hukum di Samudera-Pasai berdasarkan tulisan Ibn Baṭuṭah, seorang pelancong Maroko abad ke-14. ${ }^{54}$ Ia melihat dan mencatat banyak perihal praktik

\footnotetext{
52 Van Leur menjelaskan bahwa Islamisasi Nusantara lama kelamaan dilakukan dengan tujuan politik. Selain faktor ekonomi, faktor politik memainkan peranan yang penting. Lihat J.C. Van Leur, Indonesian Trade and Society (The Hague-Bandung: W. Van Hoeve LTD, 1955), 112.

${ }^{53}$ Denys Lombard, Le Carrefour Javanais Vol. 2 (Paris: Ecole des Hautes Etudes en Sciences Sociales, 1990), 33. Denys Lombard, Nusa Jawa: Silang Budaya, terj. Winarsih Arifin, Rahayu Hidayat, dan Nini Yusuf, Vol. 2 (Jakarta: Gramedia, 2000), 32.

${ }^{54}$ Ibn Baṭuțah lahir pada 24 Februari 1304 dan wafat pada 1368/1369 di Maroko. Ia adalah seorang Kadi, Shaykh, dan ulama keturunan satu keluarga hakim dan Shaykh juga. Ia berkelana keliling dunia selama hampir 30 tahun. Ia adalah seorang pengikut Mazhab Mâlikî dan paham benar Hukum Islam. Ia menjadi hakim saat dia tinggal di Maldiv. Catatannya mengenai hukum Islam di Samudera Pasai sangat penting mengingat keahliannya dalam bidang ini. Tentang Ibn Baṭuṭah lihat Herman F.
} 
Islam di Samudera Pasai. Berdasarkan catatan-catatannya, sultan Samudera-Pasai adalah seorang Muslim yang baik yang menerapkan hukum Islam. Oleh karena itu, penduduknya menjalankan aturanaturan ajaran Islam. Lebih dari itu, kesultanan Samudera-Pasai memiliki lembaga-lembaga keagamaan seperti qâḍ̂ dan muftî. Kita akan mengikuti secara lebih rinci tulisan Ibn Baṭ̂țah dalam bukunya (yang disingkat) al-Riblah ${ }^{55}$ tentang praktik hukum Islam, satu-satunya sumber mengenai hal tersebut.

Ibn Batûtah pergi ke Samudera-Pasai pada 345/346. Ia tinggal selama 15 hari dan setelah itu ia berangkat ke Tiongkok. Ia menulis:

Saya tinggal dengan penguasa ini di Sumatra (maksudnya: Samudera) selama 15 hari... saya mohon kepadanya untuk dapat meneruskan perjalanan saya... ke Tiongkok.... ${ }^{56}$

Sebelum tiba di Samudera-Pasai, Ibn Bațuttah berada di India. Perjalanannya dari India membutuhkan waktu 25 hari untuk sampai ke Sumatra. Ia menulis:

...Kami meninggalkan rakyat (India) ini, dan setelah perjalanan 25 hari, kami sampai di Pulau Jawa (maksudnya: Sumatra)... ${ }^{57}$

Saat kedatangannya, Ibn Bațuttah disambut oleh Bohruz, wakil laksamana, yang memberitahu perihal ini kepada sultan. Setelah mengerti akan kedatangannya, sultan pun menyuruh Amir Dawlasah untuk menemuinya. Selanjutnya, Dawlasah, Hakim Amir Sayyid alSyirazi, Fakih Tajuddin al-Isfahan, dan para fukaha lainnya

Jannsens, Ibn Batouta: Le Voyageur de l'Islam (1304-1369) (Bruxelles: Office de Publicité, 1948), 5-7.

55 Ibn Batûtah, al-Riḥlah, Voyages d'Ibn Batûtah 1325-1354, C. Defremery dan B.R. Sanguinetti, (eds.)., Vol. 4 (Paris: Anthropos, 1854), 228-240. Buku ini tidak ditulis oleh Ibn Batûtah sendiri, tetapi oleh Ibn Juzayy al-Kalbî. Sultan Abû 'Inan menyuruh Batûtah untuk mendikte ingatan-ingatan perjalanannya kepada sekretarisnya Ibn Jujayy, seorang terdidik Andalusi yang berasal dari Granada. Buku tersebut ditulis dari 9 Desember 1355 sampai Februari 1356. Judul asli buku tersebut adalah Tuhfat al-Nuzzâr fì Gharâib al-Amsâr wa Aghâib al-Asfâr, tetapi lebih dikenal dengan al-Rihlah. Lihat juga catatan yang amat bagus dari Paule Charles Dominique dalam Ibn Batûtah, "Voyages et Périple (al-Rị̣lah)", di dalam buku Voyageur Arabes, disunting dan diberi catatan oleh Paule Charles-Dominique (Paris: Gallimard, 1995), 1130-1149, dan 'Pendahuluan dan Catatan' oleh Stéphane Yerasimos dans Ibn Batûtah, Voyages, Vol. 1, terj. C. Defremery dan B. R. Sanguinetti (Paris: François Maspero, 1982).

${ }^{56}$ Bațutạ, al-Rị̣lat, 239.

${ }^{57}$ Ibid., 228. 
menyambut Ibn Bațûtah. Mereka pergi menuju ibu kota Samudera dengan berkuda.

...Kemudian, Sultan memerintahkan kepada Amir Dawlasah untuk datang menemuiku, ditemani oleh yang mulia Hakim Amir Sayyid al-Syirazide Chirâz dan Tajuddin al-Ispahani dan fukaha yang lain... Aku naik kuda dan demikian juga para pelayanku. Kami berkuda memasuki ibu kota, yaitu kota Sumatra (maksudnya: Samudera). ${ }^{58}$

Ibn Baṭ̂tah kemudian bicara mengenai sultan dan penduduknya, demikian juga tentang penerapan hukum Islam:

Ini perihal Sultan Malik al-Zahir, salah satu raja yang paling terkenal dan paling dermawan. Ia menganut mazhab Shâfi $\hat{i}$. Ia mencintai para fukaha yang datang ke pertemuan-pertemuannya untuk membaca al-Qur'ân dan mengadakan pengajian. Ia selalu berperang, terutama berihihad melawan para kafir. Ia sangat sederhana dan datang berjalan kaki untuk salat Jumat. Rakyatnya juga mengikuti mazhab Shâfîî. Mereka suka berjihad melawan orang-orang musyrik dan berperang dengan semangat bersama raja mereka. Mereka meraih kemenangan terhadap orang-orang kafir yang menjadi tetangga kerajaan mereka. Orang-orang kafir itu membayar jizyah untuk mendapatkan perdamaian. ${ }^{59}$

Ibn Batûtah menulis lagi tentang apa yang dilakukan oleh sultan setelah salat Jumat:

Kemudian, sultan mengadakan pengajian yang ia kuasai tentang fiqh mazhab Shâfîî dan ia lanjutkan hingga masuk waktu salat Asar. ${ }^{60}$

Teks di atas memberitahu kita tentang hukum Islam dan penerapannya di Samudera-Pasai: tentang mazhab fiqh, qâd $\hat{\imath}$ dan fakih, jihad, dan jisyah. Tetapi, sebelum membicarakan hal hukum Islam ini, penting untuk memastikan siapakah Sultan Malik al-Zahir yang Ibn Batûtah temui saat tinggal di Samudera-Pasai. Masalahnya ada pada nama Malik al-Zahir, karena hampir semua sultan Samudera-Pasai menggunakan nama ini dan dianggap sebagai gelar seorang sultan. ${ }^{61}$ Juga, nama tersebut adalah gelar bagi raja-raja Muslim di India dan di

\footnotetext{
${ }^{58}$ Ibid., 230.

${ }^{59}$ Ibid.

${ }^{60}$ Ibid., 235.

${ }^{61}$ Hill, "Hikayat Raja-raja Pasai”, 16.
} 
Mesir yang diikuti oleh para sultan Samudera-Pasai. ${ }^{62}$ Oleh sebab itu, sangat sulit untuk mengetahui siapakah sebenarnya Malik al-Zahir saat itu. Alfian memperkirakan bahwa sultan itu adalah sultan Mansur (1326- ?). ${ }^{63}$ Akan tetapi, Hill mengajukan hipotesis lain, yaitu sultan yang menemui Ibn Baṭ̂țah adalah Sultan Ahmad (1346-1383). Pengajuan hipotesis terakhir itu tidak benar, karena menurut Ibn Bațuttah, sultan itu adalah orang yang amat baik, padahal Hikayat Rajaraja Pasai memberikan citra seorang sultan yang memiliki sifat buruk yang telah membunuh putranya dan memperkosa putrinya. ${ }^{64}$ Demikian juga masalah tahun kunjungan Ibn Baṭ̂tah masih dalam perdebatan. Ditambah lagi, tanggal yang ditunjukkan oleh Ibn Baṭ̂tạ tidak selalu bertepatan dengan tanggal masa tinggalnya, karena Ibn Batûtah tidak menuliskan catatannya langsung, tetapi ia ditekan kemudian kepada Ibn Juzayy. ${ }^{65}$ Mungkin sekali Ibn Baṭ̂țah salah. Ivan Hrbek, orientalis Ceko, mengatakan bahwa kendati tanggal dan urutan peristiwa dalam buku al-Riblah salah atau tidak tepat, peristiwanya sendiri secara keseluruhan adalah benar. ${ }^{66}$ Dengan demikian, peristiwa-peristiwa itu adalah benar adanya dan karenanya Ibn Batûtah adalah saksi langsung tentang apa yang terjadi di Samudera-Pasai pada abad ke-14 semasa kunjungannya.

\section{Mazhab Hukum Islam}

Ibn Baṭutah mengatakan bahwa mazhab hukum Islam yang sultan dan penduduknya ikuti adalah mazhab Shâfîî. ${ }^{67}$ Ibn Baṭ̂tạ juga mencatat bahwa sultan mengikuti mazhab Shâfíî dan bahkan sultan mengajarkan fiqh mazhab Shâficî. ${ }^{68} \mathrm{Hal}$ ini menunjukkan bahwa pada abad ke-14, umat Islam di Samudera-Pasai telah mengikuti mazhab Shâfî̀.

Mazhab Shâfî̀ masuk ke Nusantara bersamaan dengan kedatangan Islam. Seperti telah dijelaskan di atas, bahwa Nusantara adalah jalur penting untuk perdagangan internasional dari Barat ke Timur. Pusat-pusat perdagangan di Timur Tengah seperti Kairo,

\footnotetext{
${ }^{62}$ Ibid, 19, dan Schrieke, Indonesian Sociological Studies, Vol. 2, 261.

${ }^{63}$ Alfian, Kronika Pasai, 18 dan 21.

${ }^{64}$ Hill, "Hikayat Raja-raja Pasai", 19.

${ }^{65}$ Lihat catatan No. 78.

66 “The Chronology of Ibn Batûtah's Travels", Achiv Orientalni, Prague, 30, 1967, 407-486.

${ }^{67}$ Bațuttah, al-Rị̣lat, 230.

${ }^{68}$ Baṭ̂țah, al-Rị̣lat, 235.
} 
Jeddah, dan Aden di Yaman secara mayoritas adalah penganut mazhab Shâfîî karena mazhab fiqh tersebut berasal dari Kairo di mana Shâfîi menghabiskan tahun-tahun akhir kehidupannya. Dari Kairo, mazhab Shâfîî menyebar ke mana-mana. Mazhab tersebut mungkin berdampingan dengan mazhab lain di Mesir, Irak, Khurasan (Iran Timur-Laut, Afganistan Utara, dan Turkmenistan), ${ }^{69}$ Turan (Iran Timur-Laut dan Turki), ${ }^{70}$ Syam (Suriah, Palestina, dan Yordania), ${ }^{71}$ Yaman, Hadramawt, Mâ Warâ’ al-Nahar (Uni Sovyet Selatan dari Oxus sampai ke Yaksarat), ${ }^{72}$ Persia, Qumis, Tabaristan, Rayy, Azerbaijan, al-Gibal, Isfahan, Maghrib, India, Afrika, dan Andalusia setelah abad ke-3 H./9 M. $^{73}$ Mazhab Shâfîî diuntungkan oleh kemenangan Dinasti Saljuk atas Dinasti Fâtimîyah pada abad ke-9 sampai ke-13 M. di Kairo. ${ }^{74}$ Mazhab Shâfîî menjadi mazhab resmi negara kerajaan sepanjang masa Ayyûbîyah dan Mamlûk. ${ }^{75}$

Kita ketahui bahwa Semenanjung Arab, Persia, dan India merupakan negeri-negeri yang melakukan perdagangan dengan Nusantara. Adalah mungkin di antara para pedagang tersebut, di antaranya beragama Islam dan mengikuti mazhab Shâfi î. Ini alasan mengapa Cahen beranggapan bahwa mazhab Shâfî̀ berasal dari Kairo, Mesir. ${ }^{76}$ Mungkin sekali merekalah yang mengajarkan dan menyebarkan mazhab Shâfi î. Pijnappel menulis bahwa orang-orang Arab bermazhab Shâficî berimigrasi dan menetap di daerah India, terutama di Gujaran dan di Malabar, dan merekalah yang membawa Islam ke Nusantara. ${ }^{77}$

\footnotetext{
${ }^{69}$ Louis Ma'lûf, al-Munjid fî al-A 'lâm (Beirut: Dâr al-Mashriq, 1986), 267.

70 Ibid., 195.

${ }^{71}$ Ibid., 382.

72 Ibid., 357.

73 Aḥmad Taymûr Bâshâ, al-Madhâhib al-Fiqhîyah al-Arba'ah (Beirut: Dâr al-Kâdirî, 1990), 70-80. Lihat juga buku yang amat bagus tentang penyebaran mazhab Shâfi î̀ sejak awal pendiriannya hingga abad ke-8/14 di dunia: Heinz Halm, Die Ausbreitung des Safiitischen Rechtsschule von den Anfängen bis Zum 8./14. Jabrbundert (Wiesbaden: Ludwig Reichert, 1974).

74 André Miquel, L’islam et Sa Civilisation VIIe-XXe Siècle (Paris: Armand Collin, 1977), 184.

${ }^{75}$ Bâshâ, al-Madhâhib al-Fiqhîyah, 70-80.

${ }^{76}$ Anders C. Cahen, Der Islam I (Frankfurt: t.tp, 1968), 322.

${ }^{77}$ Drewes, "New Light on the Coming of Islam to Indonesia", 130-131.
} 
Para pedagang ini menikah dengan perempuan pribumi. $^{78}$ Sangat mungkin, sebelum pernikahan, para perempuan pribumi tersebut masuk Islam agar bisa dinikahi menurut mazhab Shâfíî. Keluarga mereka juga demikian masuk agama Islam. Dengan demikian, hukum Islam memainkan peranan penting dalam mengislamkan penduduk Nusantara. ${ }^{79}$ Hukum Islam lambat laun mendapatkan tempat dalam kehidupan sehari-hari. ${ }^{80}$ Dari sana kemudian sedikit demi sedikit mazhab Shâfîi dipraktikkan. Dari Samudera-Pasai, mazhab fiqh tersebut tersebar bersamaan dengan agama Islam di seluruh Nusantara.

\section{Lembaga Pengadilan}

\section{A. Qâdî}

Ibn Bațûtah menegaskan bahwa telah ada lembaga pengadilan di Samudera-Pasai. Kita mengetahui keberadaan qâḍ̂̀ di kesultanan ini, yaitu Qậ̂̀ Amîr Sayyid al-Shirâzî. ${ }^{81}$ Dengan memerhatikan bahwa ia berasal dari Syiraz, qâd dominasi mazhab Shâfi'î di Samudera-Pasai, karena Syiraz merupakan salah satu kota yang mengikuti mazhab Shâfîî. ${ }^{82}$

Menurut hukum Islam, qậ̂̀ mengeluarkan keputusan berdasarkan sharî‘ ah dalam kasus-kasus di mana dua pihak saling berselisih. ${ }^{83}$ Qâd $\hat{\imath}$ adalah seorang hakim, pejabat yang berwenang yang melaksanakan kekuasaan peradilan (qadâ $)^{84}$ yang menjamin sistem islami dan mengatur peradilan. ${ }^{85}$ Oleh karena itu, qâḍ̂ adalah seorang pegawai negara dan juga perwakilan dari gubernur. Sultan yang mengangkat

\footnotetext{
78 Rudolf Aernoud Kern, "The Propagation of Islam in the Indonesian-Malay Archipelago", (ed.) Alijah Gordon (Kuala Lumpur: Malaysian Sociological Research Institute (MSRI), 2001), 28-29. Lihat juga G.H. Bousquet, "Introduction à l'Etude de l'Islam Indonésien”, Revue des Etudes Islamiques, Cahiers II-III, 1938, 159.

${ }^{79}$ Syed Muhammad Naguib al-Attas, Islam and Secularism (Kuala Lumpur: ISTAC, 1993), 170.

${ }^{80}$ Kern, “The Propagation of Islam”, 28-29.

${ }^{81}$ Batûtạ, al-Rị̣lat, 230.

${ }^{82}$ Halm, Die Ausbreitung, 151-152.

83 Shams al-Dîn b. Aḥmad al-Sharbînî, al-Iqnâ' fî Hẹall Alfâz. Ab̂̂ Shujâ', disunting oleh 'Ali 'Abd al-Hamîid Abû al-Hayr dan Muhammad Wahbî Sulaymân, Vol. 2 (Damaskus: Dâr al-Hayr, 1996), 850-851.

${ }^{84}$ E. Tyan, "Kadi", dans Encyclopédie de l'Islam (Leiden dan Paris: E.J. Brill dan G.P. Maisonneuve, 1977), 390-391.

${ }^{85}$ Joseph Schacht, Introduction au Droit Musulman, terj. Paul Kempf dan Abdel Magid Turki (Paris: Maisonneuve dan Larose, 1999), 25.
} 


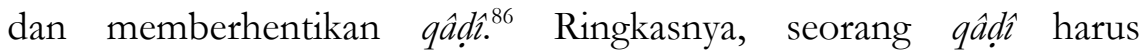
mempunyai tiga kemampuan: mengurus perihal administratif (mengurus wakaf, menjadi wali, dll.), mengurus perihal kepentingan umum (mengatur administrasi publik, mengawasi masyarakat, jalan umum, dan jihad), dan mengurus perihal keagamaan (memimpin ibadah, khutbah, ceramah, dan lain-lain). ${ }^{87}$

Qậ̂̀ di Samudera-Pasai kemungkinan memiliki wewenang dan jabatan seperti yang diterangkan dalam hukum Islam. Ibn Baṭuțah menulis bahwa Qâdî Amir Sayyid al-Syirazi, untuk menemani Amir Dawlasah, yang menyambutnya. Penulis berpikir bahwa mereka adalah pejabat dan wakil dari Sultan yang menyambut tamu negara, seperti Ibn Baṭ̂țah. Kita juga dapat memerkirakan bahwa qâd kesultanatan Samudera-Pasai ditunjukan dan diberhentikan oleh sultan, karena ia memiliki kekuasaan yang besar seperti pada kesultanan lainnya.

Adapun yang terkait dengan wewenang keagamaannya, Ibn Bațuttah menulis bahwa qâdı̂ berada di samping sultan saat Ibn Bațûtah menemui qâdî setelah salat. ${ }^{8}$ Kami menduga bahwa mungkin salat diatur dan dipimpin oleh qâdî. Ia juga mengikuti pengajian atau ceramah tentang hukum Islam menurut mazhab Shâfi î bersama dengan sultan, para pelajar, dan masyarakat. Qâdî melakukan perang suci, seperti penduduk Samudera-Pasai lainnya. Adalah mungkin, qâd $\hat{\imath}$ mencoba membangun lembaga peradilannya sendiri sebagaimana terdapat di dalam kesultanan lainnya di dunia Muslim.

\section{B. Fakih}

Menurut hukum Islam, fakih adalah seseorang yang memiliki pengetahuan (fiqh). Pengertian fiqh-yang secara etimologis berarti "pemahaman"— ${ }^{89}$ adalah ilmu pengetahuan yang suci yang menggali sumber-sumber utama dalam Islam, yaitu al-Qur'ân, Sunnah, Ijmấ, dan Qiyâs. Ia yang mempraktikkan fiqh disebut fakih dan usahanya mencari jawaban dari sharı̂‘ah, yang disebut sebagai ijtihad. Fakih dapat mengeluarkan pendapatnya tentang hukum Islam yang lebih masuk akal atau lebih cocok dengan keadaan atau tujuan politik. ${ }^{90}$

\footnotetext{
${ }^{86}$ Ibid., 13, 21, 32, 33.

87 Bleuchot, Droit Musulman, Vol. 2, 625-626.

${ }^{88}$ Batûtah, al-Rip̣lat, 234-235.

${ }^{89}$ Ibn Manzûr, Lisân al-'Arab, Vol. 5 (Beirut: Dar al-Ma‘ârif, t.th.), 3450.

${ }^{90}$ Bleuchot, Droit Musulman, Vol. 1, 17-18.
} 
Ringkasnya, figh adalah ilmu hukum Islam orang yang menguasai ilmu tersebut disebut fakih, yaitu seorang ahli hukum (yuris). ${ }^{91}$

Fakih, menurut penulis, juga adalah seorang mufti. Mufti adalah seorang fakih yang dapat memberikan suatu pendapat mengenai persoalan dalam agama. Pendapat hukumnya yang amat dihargai mengenai persoalan-persoalan masyarakat atau agama disebut fatwa. Tugas utama dari mufti adalah memberitahu orang yang bertanya tentang tata-cata yang benar dalam hubungannya dengan Sharî‘'ah. Pendapat seorang mufti tidak memiliki sanksi hukum resmi. Mufti dapat memberikan pendapat pribadinya tentang masalah-masalah keagamaan dengan mengikuti ajaran-ajaran mazhab kepada masyarakat dan juga kepada para pejabat pemerintahan. ${ }^{92}$

Ibn Bațutah memberitahu kita bahwa sultan, qâdî̀, faqîh, dan para pelajar belajar hukum Islam mazhab Shâfîi setiap sebelum salat Jumat. ${ }^{93}$ Adalah sangat mungkin pada masa itu, fakih sebagaimana juga mufti, memberikan pendapatnnya kepada semua orang (pelajar dan masyarakat) dan kepada para pejabat pemerintahan (sultan dan para pembesar kerajaan). Mungkin juga qâdı̂ pada saat itu berkonsultasi kepada mufti untuk memecahkan persoalan-persoalan sulit. Di dalam hukum Islam, qâd ulama ketika ia dalam kesulitan atau kepada para mufti resmi yang seringnya juga bertugas di pengadilan para qậ̂̉ ${ }^{94}$ Penulis menduga ada

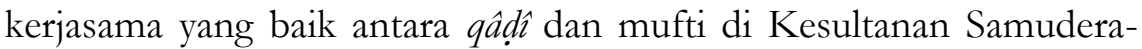
Pasai, sebagaimana ditunjukkan dalam pengajian Jumatan dan saat menyambut Ibn Baṭuțah oleh dua qâdî dan para fakih.

Pemerintahan Islam menunjuk ulama yang memiliki kemampuan mumpuni sebagai mufti resmi ${ }^{95}$. Sebagai negara Islam, jelas bahwa sultan Samudera-Pasai menunjuk beberapa mufti resmi. Ibn Batûtah menjelaskan bahwa fungsi mufti adalah sangat penting di dalam kesultanan. Sang mufti duduk dalam ruang pertemuan bersama dengan sekretaris, para pimpinan tentara, komandan, dan pembesar

${ }^{91}$ D.B. Macdonald, "Fakih", dalam Encyclopédie de l'Islam (Leiden dan Paris: E.J. Brill dan G.P. Maisonneuve, 1977), 774. Lihat juga I. Goldziher dan J. Schacht, "Fiqh", dalam Encyclopédie de l'Islam (Leiden dan Paris: E.J. Brill dan G.P. Maisonneuve, 1977), 906-908.

92 Schacht, Introduction, 66. Lihat juga E. Tyan, "Fatwa", dalam Enclopédie de l'Islam (Leiden dan Paris: E.J. Brill dan G.P. Maisonneuve, 1977), 886.

${ }^{93}$ Batûtah, al-Rihlat, 235.

94 Schacht, Introduction, 66.

${ }^{95}$ Ibid. 
kerajaan. ${ }^{96}$ Mufti sebagai pejabat resmi kesultanan sebagaimana pejabat yang lain. Sultan sangat menghargainya. ${ }^{97}$

Adapun yang terkait dengan fungsi mufti, penulis memperkirakan bahwa mungkin di kesultanan Perlak terdapat majlis fatwâ, yang dipimpin oleh seorang mufti yang menangani persoalan-persoalan hukum agama. Jabatan tersebut berada di atas kementerian kehakiman (wizâarat al-hukkâm). Sistem tersebut berlanjut hingga ke masa pembentukan kesultanan Samudera-Pasai. ${ }^{98}$ Oleh karena itu, adalah mungkin ada seorang mufti di kesultanan Samudera-Pasai.

\section{Wilayah antara Dâr al-Islam dan Dâr al-Harb}

Ibn Batûtah menekankan bahwa sultan dan rakyatnya suka berjihad melawan para kafir. ${ }^{99}$ Jihad adalah perang bersenjata di jalan Allah (fì sabîl Allâh) melawan orang-orang yang tidak beriman. ${ }^{100}$ Menurut Imam Shâfi $\hat{1}$, jihad merupakan kewajiban yang baik dan suci. ${ }^{101}$ Untuk para fukaha, tidaklah diragukan bahwa tujuan jihad adalah menaklukkan dunia, menjalankan hukum Islam dan mengislamkan mereka. Negara Islam menjadi negara imperial dan ekspansionis yang berusaha mengalahkan orang lain dengan pengislaman. Jihad adalah alat dan strategi untuk perluasan politik, sosial, dan keagamaan. ${ }^{102}$

Para fukaha membagi dunia menjadi dua wilayah politikkeagamaan: Dâr al-Islâm, daerah Islam atau wilayah orang Islam, dan Dâr al-Harb, daerah perang atau wilayah musuh. Dâr al-Islâm adalah daerah yang dikuasai oleh orang Islam dan Dâr al-Harb daerah di luar kekuasaan orang-orang Islam. Di dalam Dâr al-Islam, hukum Islam diterapkan kepada semua rakyat, sementara di dalam Dâr al-Ḥarb, hukum Islam tidak berlaku. Dâr al-Islâm, dalam keadaan terus berperang dengan Dâr al-Harar, menawarkan syarat penghentian permusuhan, yaitu Dâr al-H țarb menyatakan takluk atau menyerahkan diri. ${ }^{103}$ Dengan demikian, orang-orang bukan-Islam dihadapkan pada

\footnotetext{
${ }^{96}$ Batûtah, al-Riḥlat, 236.

${ }^{97}$ Ibid., 230.

98 Ibrahim dan Sufi, "Sekelumit Pendapat tentang Proses Islamisasi”, 20-21.

${ }^{99}$ Batûtah, al-Rihlat, 230.

100 al-Sharbînî, al-Iqnâ', 770. Kewajiban jihad berdasarkan Q.S. 2: 216, 9:36 dan 5:89.

101 Muhammad b. Idrîs al-Shâfîî, al-Umm, disunting oleh Muhammad Zuhrî alNajjâr, Vol. 2 (Beirut: Dâr al-Ma'rifah, t.th.), 161.

102 Bleuchot, Droit Musulman,Vol. 2, 586, 590, 615.

103 Ibid., 589.
} 
tiga pilihan: masuk agama Islam, dibunuh, atau takluk kepada pemerintahan Islam dengan membayar pajak atau jizyah sebagai jaminan perlindungan. ${ }^{104}$

Jika orang-orang bukan-Islam masuk ke dalam agama Islam, maka jihad berhenti. ${ }^{105}$ Jika tidak, maka orang-orang tersebut menyatakan takluk dan dapat tinggal di daerah yang dikuasai oleh orang Islam dengan syarat membayar jisyah. ${ }^{106}$ Para fukaha mendasarkan pendapat mereka atas firman Allah, "Perangilah mereka hingga mereka membayar jizyah dengan tangan mereka...". ${ }^{107}$ Jiøyah, berasal dari kata kerja jazâ, berkait dengan sejumlah uang dibayarkan kepada penguasa Islam (Dâr al-Islâm). ${ }^{108}$ Orang yang membayar jizyyah dinamakan abl aldhimmah atau dhimmî. ${ }^{109}$ Al-Jurjânî, seorang ahli bahasa Arab (740816/1340-1413), berpendapat dhimmah itu seperti suatu perjanjian. ${ }^{110}$ Bagi Ibn Manzûur, ahli bahasa Arab dan seorang qậ̂̀ yang meninggal di Kairo (630-711/1232-1311), dhimmah adalah juga suatu perjanjian, serta keamanan, jaminan, kehormatan dan hak, karena abl al-dhimmah adalah orang-orang yang kita tagih jiayah agar mereka memeroleh perlindungan atas jiwa dan harta mereka. ${ }^{111}$

Hanya pria yang membayar jisyah, perempuan, anak-anak dan orang tua dibebaskan dari pembayaran jisyah. Menurut ahli fiqh

104 Berdasarkan hadîth Nabi, "Jika kamu menemui orang-orang kafir, mintalah mereka untuk masuk Islam. Jika mereka mentaati, hal itu sudah cukup. Jika mereka menolak, mintalah kepada mereka untuk membayar jizyah. Jika mereka patuh, hal itu sudah cukup. Jika tidak, bertawakallah kepada Allah dan perangilah mereka. Namun, jika mereka masuk agama Islam atau membayar jizyah, hal itu sudah cukup”.

105 E. Tyan, "Djihad", dalam Encyclopédie de l'Islam (Leiden dan Paris: E.J. Brill dan G.P. Maisonneuve, 1977), 551-553.

106 Muhammad b. al-Ghazâlî, al-Wasît fî al-Madhhab, disunting oleh Aḥmad Mahmûd Ibrâhîm dan Muhammad Muhammad Tâmir, Vol. 7 (Kairo: Dâr al-Salâm, 1997), 55. 107 Q.S. al-Tawbah [9]: 29.

108 Jumlah jizyah adalah 1 dinar berdasarkan tulisan Muaz. Saat ia sedang bersiap-siap berangkat ke Yaman, Nabi memintanya agar menarik 1 dinar atau yang setara dengan 1 pakaian kepada setiap orang dewasa di Yaman, lihat Sayyid Sâbiq, Fiqh alSunnah, Vol. 3 (Kairo: t.tp., 1988/1409), 64. Kendati demikian, tidak ada yang mengatakan bahwa jumlah jizyah adalah 1 dinar (12 dirham) bagi orang miskin, 2 dinars (24 dirham) bagi kelas menengah, dan 4 dinars (48 dirham) bagi orang kaya, lihat C.H. Becker, "Djizya", dans Encyclopédie de l'Islam (Leiden dan Paris: EJ. Brill dan Picard, 1913), 1082.

${ }^{109}$ Sâbiq, Fiqh al-Sunnah, Vol. 3, 65.

110 'Ali ibn Muhammad al-Jurjânî, Kitâb al-Ta'rifât (Beirut: Maktabat Lubnan, 1978), 112.

${ }^{111}$ Ibn Manzûr, Lisân al-'Arab, Vol. 3, 1517. 
Shâfîî, Imam al-Sharbînî (w. 977/1569), tujuan pembayaran jiżyah adalah menundukkan orang bukan-Islam dan mendorong mereka untuk masuk agama Islam ${ }^{112}$. Orang bukan-Islam yang menolak pindah agama Islam dan tunduk kepada pemerintahan Islam dipanggil harbî, atau musuh asing; mereka tinggal di daerah kafir. Hidup dan barang mereka tidak dijamin oleh undang-undang. ${ }^{113}$

Abl al-dhimmah hidup bersama dengan umat Islam di dalam wilayah Islam. Hukum Islam diterapkan kepada semua penduduk Dâr al-Islâm, Muslim atau bukan. Artinya, hukum untuk dhimmî sesuai dengan hukum Islam. ${ }^{114}$ Menurut Imam Shâfiî̀ kalimat wa hum sâghirûn di dalam al-Qur'ân ${ }^{115}$ berarti hukum Islam berlaku bagi orang bukanIslam. ${ }^{116}$ Kendati demikian, penerapan tersebut benar-benar terbatas dengan wilayah. Artinya, hukum Islam tidak berlaku bagi mereka yang tinggal di luar negara Islam (Dâr al-Islâm). ${ }^{117}$ Pelaksanaan jihad, jiàyah, dan pemisahan wilayah Islam dan bukan-Islam di Kesultanan Samudera-Pasai berkait dengan pemikiran dan aturan hukum Islam.

Odorigo de Pordenone, seorang pendeta Fransiskan, sebelum kedatangan Ibn Batûtah, telah mengunjungi Samudera-Pasai pada 1323. Ia memberitahukan kita bahwa kerajaan (-Pasai) selalu berperang dengan kerajaan tetangga Lamuri, yang saat itu belum Islam. ${ }^{118}$ Raja saat itu adalah Muhammad Malik al-Zahir (1297-1326), kakek sultan Ahmad Malik al-Zahir (1346-1383). Ia berperang suci (jihad) melawan orang-orang bukan-Islam agar mereka tunduk kepada penguasa Muslim. Perang suci tersebut berlanjut saat kunjungan Ibn Batûtah. Dikatakan dalam catatan Ibn Baṭ̂tạh bahwa sultan Ahmad adalah seorang yang amat saleh dan berjihad bersama dengan rayatnya melawan orang-orang bukan Islam.

Jihad berlanjut, karena Samudera-Pasai berada di dalam wilayah Islam yang telah menjadi kesultanan, sementara kerajaan-kerajaan

\footnotetext{
112 al-Sharbînî, al-Iqnâ', 788.

113 Schacht, Introduction, 112.

${ }^{114}$ Hasan al-Mimmî, Ahl al-Dhimmah fì al-Ḥadâarah al-Islâmîyah (Beirut: Dâr al-Gharb al-Islâmî, 1998), 27.

115 Q.S. al-Tawbah [9]: 29.

116 al-Shâfî̀̂, al-Umm, 176.

117 Louis Millot dan François-Paul Blanc, Introduction à L'étude du Droit Musulman (Paris: Sirey, 1987), 226.

118 Bressan, "Odoric of Pordenone", 18. Kern, "The Propagation of Islam", 34, dan 89-90. Negeri-negeri tetangga Samudera-Pasai adalah Lambri (Lamuri), Dragoian, dan Fansur. Mereka adalah para penyembah berhala sebagaimana dikatakan oleh Marco Polo, lihat Polo, Le Devisement Du Monde, 412.
} 
tetangga berada di dalam wilayah kafir. Jadi, mereka harus dikalahkan dan ditaklukkan di bawah penguasa Islam. Perang tersebut tidak akan berhenti sampai mereka menerima Islam dengan pindah agama ke dalam agama Islam. Jika tidak, maka mereka harus membayar jizyah. Ibn Baṭuttah memberitakan bahwa kerajaan-kerajaan tetangga Samudera-Pasai yang kafir membayar jisyah untuk mendapatkan perdamaian (sulh). Inilah yang kita sebut sebagai Dâr al-Ṣulh (wilayah damai), corak ketiga selain wilayah Islam dan wilayah kafir. Corak ketiga itu ditujukan bagi negara-negara yang 'membeli' perdamaian dengan jizyah. Dalam masalah ini, Islam mengajukan hubungan damai dengan pertukaran, yaitu membayar ganti-untung dengan uang (jizyah). Ini adalah keadaan damai sementara dan dibutuhkan oleh keadaan. ${ }^{119}$

Penerapan hukum Islam terus berlaku hingga akhir sultan Samudera-Pasai. Sumber Portugal memberitahu kita bahwa raja Samudera-Pasai, Jeinal, yaitu Zainal 'Abidin, telah meminta jizyah kepada kaum minoritas. ${ }^{120}$ Penulis memperkirakan bahwa mereka adalah orang-orang bukan-Islam yang tinggal di dalam wilayah Islam dan mereka membayar jizyah untuk dapat hidup di dalam negara tersebut. Kita juga tahu bahwa dengan jihad, kesultanan SamuderaPasai menjadi besar. ${ }^{121}$

\section{Penutup}

Hukum Islam di Samudera-Pasai hanyalah sebagian hukum yang diterapkan di samping hukum adat. Hukum Islam tidak diterapkan secara kaku. Di dalam Hikayat Raja-raja Pasai, saat Sultan Ahmad membunuh anak lelakinya dan memperkosa anak perempuannya, ia tidak dihukum mati. Selain itu, mazhab Shâfîî yang diikuti di Samudera-Pasai itu sangat lentur, bahkan tidak terlalu benar-benar diikuti. Menurut mazhab Shâfi $\hat{i}$, negara-negara tetangga yang takluk kepada Samudera-Pasai harus memiliki salah satu agama samawi, Nasrani atau Yahudi. Jika mereka adalah para penyembah berhala, menurut Imam Shâfî̀, pemerintahan Islam tidak bisa menerima jizyah. ${ }^{122}$ Pemerintahan Islam harus mengajukan dua pilihan kepada

119 Alfred Morabia, "La Notion de Djihâd dans l'Islam Médiéval" (Disertasi-Universitas Paris IV, 1974), 315-316.

${ }^{120}$ William Marsden, The History of Sumatra (London: Oxford University Press, 1966), 408.

${ }^{121}$ Bousquet, "Introduction à l'Etude", 160.

122 al-Shâfîî, al-Umm, Vol. 4, 174. 
para penyembah berhala: menjadi Islam atau dibunuh. Sesungguhnya, kerajaan-kerajaan tetangga Samudera-Pasai adalah para penyembah berhala. Kendati demikian, mereka membayar jisyah dan kesultanan menerimanya. Umat Islam di Samudera-Pasai tidak mengikuti secara harfiah mazhab Shâfî̀. Bisa katakan bahwa hukum Islam dilaksanakan secara terbatas, seperti jihad, kewajiban membayar jizyah bagi orang bukan-Islam, penerapan konsep kewilayahan, dan keberadaan lembaga-lembaga keagamaan, seperti qâdı̂ dan fakih di kesultanan Samudera-Pasai. Karena sedikit bukti, sulit bagi penulis untuk mengetahui secara lebih pasti bagaimana penafsiran sharî‘'ah. Kendati demikian, pemaparan di sini sudah memberikan gambaran bagi kita tentang hukum Islam yang diterapkan di kesultanan Samudera-Pasai pada abad ke-14.

\section{Daftar Rujukan}

al-Attas, Syed Muhammad Naguib. Islam and Secularism. Kuala Lumpur: ISTAC, 1993.

-----. Preliminary Statement on a General Theory of the Islamization of the Malay-Indonesian Archipelago. Malaysia: Dewan Bahasa dan Pustaka, 1969.

Alfian, Teuku Ibrahim. Kronika Pasai: Sebuah Tinjauan Sejarah. Yogyakarta: Gadjah Mada University Press, 1973.

Ambary, Hasan Muarif. "Peranan Beberapa Bandar Utama di Sumatera Abad 7-16 M. dalam Jalur Sutera Melalui Lautan", Kalpataru Majalah Arkeologi, edisi Saraswati Esai-Esai Arkeologi, No. IX, 1990.

----. Menemukan Peradaban: Arkeologi dan Islam di Indonesia, sunt. Jajat Burhanuddin. Jakarta: Puslit Arkenas, 1998.

Bâshâ, Aḥmad Taymûr. al-Madhâbib al-Fiqhîyah al-Arba'ah. Beirut: Dâr al-Kâdirî̀, 1990.

Baṭuttah, Ibn. al-Riḥlah, Voyages d'Ibn Batûtah 1325-1354, C. Defremery dan B.R. Sanguinetti, (eds.)., Vol. 4. Paris: Anthropos, 1854.

Becker, C.H. "Djizya", dans Encyclopédie de l'Islam. Leiden dan Paris: EJ. Brill dan Picard, 1913.

Bleuchot, Hervé. Droit Musulman, Vol. 1. Aix-en-Provence: Presses Universitaires d'Aix Marseille, 2002.

Bressan, L. "Odoric of Pordenone (1265-1331): His Vision of China and South-East Asia and His Contribution to Relations between Asia and Europe", Journal of the Malayan Branch Royal Asiatic Society, LXX, No. 2, 1997. 
Broomhall, Marshall. Islam in China: a Neglected Problem. London: Morgan \& Scott ltd., 1905.

Cahen, Anders C. Der Islam I. Frankfurt: t.tp, 1968.

Coedès, G. Les Etats Hindonisés d'Indochine et d'Indonésie. Paris: De Boccard, 1989.

Damais, Louis-Charles. "L'épigraphie Musulmane dans Le Sud-est Asiatique", Bulletin de l'Ecole Française d'Extrême Orient, Vol. LIV, 1968.

Dominique, Paule Charles. dalam Ibn Baṭ̂tạah, "Voyages et Périple (al-Riblab)", di dalam buku Voyageur Arabes, disunting dan diberi catatan oleh Paule Charles-Dominique. Paris: Gallimard, 1995.

Drewes, G.W.J. "New Light on the Coming of Islam to Indonesia", The Propagation of Islam in the Indonesian-Malay Archipelago, Alijah Gordon (ed.). Kuala Lumpur: Malaysian Sociological Research Institute, 2001.

E. Tyan, "Fatwa", dalam Enclopédie de l'Islam. Leiden dan Paris: E.J. Brill dan G.P. Maisonneuve, 1977.

Fatimi, S. Q. Islam Comes to Malaysia. Singapore: Malaysian Sociological Research Institute, 1963.

Ferrand, G. L'empire Sumatranais de Srinijaya. Paris: Journal Asiatique, 1922.

Bousquet, G.H. "Introduction à l'Etude de l'Islam Indonésien”, Revue des Etudes Islamiques, Cahiers II-III, 1938.

Ghazâlî (al), Muhammad b. al-Wasît fì al-Madhhab, disunting oleh Aḥmad Maḥmûd Ibrâhîm dan Muḥammad Muḥammad Tâmir, Vol. 7. Kairo: Dâr al-Salâm, 1997.

Goldziher, I. dan Schacht, J. "Fiqh", dalam Encyclopédie de l'Islam. Leiden dan Paris: E.J. Brill dan G.P. Maisonneuve, 1977.

Groeneveldt, W. P. "Notes on The Malay Archipelago and Malacca Compiled Form Chinese Sources", Verbandelingen Van Het Bataviaasch Genootschap Van Kunsten En Wetenschappen, XXXIX, No. $1,1877$.

Guillot, Claude. Wawancara. Paris, 25 Mei 2004.

Gupta, Arun Kumar Das. "Acheh in Indonesian Trade and Politics 1600-1641”. Disertasi--Universitas Cornell, 1962.

Halm, Heinz. Die Ausbreitung des Sâfi'itischen Rechtsschule von den Anfängen bis Zum 8./14. Jabrbundert. Wiesbaden: Ludwig Reichert, 1974.

Hamadânî (al), Ibn al-Faqîh. al-Buldân, Abrégé du Livre des Pays, terj. Henri Masse (Damaskus: Institut Francais de Damas, 1973. 
Hill, A.H. "Hikayat Raja-raja Pasai", Journal of the Malayan Branch Royal Asiatic Society, XXXIII, No 2, 1960.

Hirth dan Rockhill dalam Chau-Ju-Kua, Chau Ju-Kua: His Work on the Chinese and Arab Trade in the Twelfth and Thirteenth Centuries, entitled Chu-Fan-Chi, terj. Friedrich Hirth dan W. W. Rockhill. St. Petersburg: The Imperial Academy of Sciences, 1911.

Ibrahim, Muhammad., dan Sufi, Rusdi. "Sekelumit Pendapat tentang Proses Islamisasi dan Munculnya Kerajaan-kerajaan Islam di Aceh", makalah yang disajikan pada Seminar Sejarah Masuk dan Berkembangnya Islam di Aceh dan Nusantara, Aceh Timur, 25-30 September 1980.

Ismail, Muhammad Gade. Pasai dalam Perjalanan Sejarah: Abad ke-13 Sampai Awal Abad ke-16, Jakarta: Departemen Pendidikan dan Kebudayaan, 1993.

I-Tsing. A Record of the Buddhist Religion as Practised in India and the Malay Archipelago. A.D. 671-695, terj. J. Takakusu. London, Oxford University Press, 1896.

Jannsens, Herman F. Ibn Batouta: Le Voyageur de l'Islam (1304-1369). Bruxelles: Office de Publicité, 1948.

Johns, A.H. "Sufism as a Category in Indonesian Literature and History", Journal Southeast Asian History, Vol. 2, No. 2, 1961.

Jones, Russel (penyunting), Hikayat Raja-raja Pasai. Kuala Lumpur: Fajar Bakti, 1987.

Ju-Kau, Chau. Chan Ju-Kua: His Work on the Chinese and Arab Trade in the Twelfth and Thirteenth Centuries, Entitled Chu-fanchi. New York: Paragon Book Reprint Corp, 1966.

Jurjânî, 'Alî b. Muḥammad. Kitâb al-Ta'rifât (Beirut: Maktabat Lubnan, 1978), 112.

Kern, Rudolf Aernoud. "The Propagation of Islam in the IndonesianMalay Archipelago", (ed.) Alijah Gordon. Kuala Lumpur: Malaysian Sociological Research Institute (MSRI), 2001.

Lanang, Tun Seri. Sulâlat al-Salatîn Ya'ni Pertuturan Segala Raja-raja: Sejarah Melayu, Muhammad Haji Salleh (ed.). Kuala Lumpur: Dewan Bahasa dan Pustaka, 1997.

Leur, J.C. Van. Indonesian Trade and Society. The Hague-Bandung: W. Van Hoeve LTD, 1955.

Lombard, Denys. Le Carrefour Javanais Vol. 2. Paris: Ecole des Hautes Etudes en Sciences Sociales, 1990. 
Lombard, Denys. Nusa Jawa: Silang Budaya, terj. Winarsih Arifin, Rahayu Hidayat, dan Nini Yusuf, Vol. 2. Jakarta: Gramedia, 2000. Ma'lûf, Louis. al-Munjid fì al-A lâm. Beirut: Dâr al-Mashriq, 1986.

Macdonald, D.B. "Fakih", dalam Encyclopédie de l'Islam. Leiden dan Paris: E.J. Brill dan G.P. Maisonneuve, 1977.

Manzûr, Ibn. Lisân al-'Arab, Vol. 5. Beirut: Dar al-Ma'ârif, t.th.

Marsden, William. The History of Sumatra. London: Oxford University Press, 1966.

Meilink-Roeflofsz, M.A.P. Asian Trade and European Influence in the Indonesian Archipelago between 1500 and About 1630. The Hague: M. Nijhoff, 1962.

Millot, Louis., dan Blanc, François-Paul. Introduction à L'étude du Droit Musulman. Paris: Sirey, 1987.

Mimmî (al), Ḥasan. Abl al-Dhimmah fì al-Ḥadârah al-Islâmîah. Beirut: Dâr al-Gharb al-Islâmî, 1998.

Miquel, André. L'islam et Sa Civilisation VIIe-XXe Siècle. Paris: Armand Collin, 1977.

Morabia, Alfred. "La Notion de Djihâd dans l'Islam Médiéval". Disertasi--Universitas Paris IV, 1974.

Mulyana, Slamet. Runtubnya Keradjaan Hindu-Djawa dan Timbulnya Negara-negara Islam di Nusantara. Jakarta: Bharata, 1968.

Penulis, Tim. Sejarah Daerah Propinsi Daerah Istimewa Aceh. Jakarta: Balai Pustaka, 1977-1978.

Pires, Tomé. The Suma Oriental Of Tome Pirés, An Account Of The East From The Red Sea To Japan, Written In Malacca And India In 15121515, Vol. 1. New Delhi: Asian Educational Services, 1990.

Polo, Marco. Le Devisement Du Monde Le Livre Des Merveilles 1250-1295, disunting oleh A.C. Moule, Louis Hambis dan Stéphane Yerasimos, Vol. 2. Paris: La Découverte, 1989.

Polo, Marco. Le Livre de Marco Polo, disunting oleh M.G. Pauthier. Paris: Firmin Didot Frères, 1865.

Ricklefs, M.C. A History of Modern Indonesia. London: The Macmillan Press, 1981.

Sâbiq, Sayyid. Fiqh al-Sunnah, Vol. 3. Kairo: t.tp., 1988/1409.

Sahriyâr, Ibn. Kitâb Aghâib al-Hind Barrih wa Babrih wa Ghazâirih (288342 H.), P. A. Van Der Lith (ed.). Leiden: E.J. Brill, 1883-1886.

Sauvaget, Jean (ed.). Akbbâr al-Sîn wa al-Hind, Relation de la Chine et de l'Inde, Les Belles Lettres. Paris: Société, 1948. 
Schacht, Joseph. Introduction au Droit Musulman, terj. Paul Kempf dan Abdel Magid Turki. Paris: Maisonneuve dan Larose, 1999.

Schrieke, B. Indonesian Sociological Studies, Vol. 2. The Hague and Bandung: Van Hoeve, 1955 dan 1957.

Shâfíî (al), Muhammad b. Idrîs. al-Umm, disunting oleh Muhammad Zuhrî al-Najjâr, Vol. 2. Beirut: Dâr al-Ma'rifah, t.th.

Sharbînî (al), Shams al-Dîn b. Aḥmad. al-Iqnâ' fì Hạll Alfẫ Abî Shujâ", disunting oleh 'Ali 'Abd al-Ḥamîd Abû al-Hayr dan Muhammad Wahbî Sulaymân, Vol. 2. Damaskus: Dâr al-Hayr, 1996.

Sirâfî (al), Sulaymân. Silsilat al-Tawârîh dan "Relations des Voyages Faits par les Arabes et les Persans dans l'Inde et à la Chine dans le IXème Siècle de l'Ere Chrétienne", Joseph Touissant Reinaud (ed.), Vol. 2. Paris: O. Zeller Verlag \& Osnabrück Allemagne, 1982.

Tibbets, G.R. "Early Muslim Traders in South-East Asia", Journal of the Malayan Branch Royal Asiatic Society, XXX, No. 1, 1957.

-----. "Pre-Islamic Arabia and South-East Asia", Journal of the Malayan Branch Royal Asiatic Society, XXIX, No. 3, 1956.

Tjandrasasmita, Uka. "The Sea Trade of the Moslems to the East Countries and the Rise of Islam in Indonesia", Makalah pada Asian History Congress, Azad Bhaven, New Delhi, 1961.

Tyan, E. "Djihad", dalam Encyclopédie de l'Islam. Leiden dan Paris: E.J. Brill dan G.P. Maisonneuve, 1977.

----. "Kadi", dans Encyclopédie de l'Islam. Leiden dan Paris: E.J. Brill dan G.P. Maisonneuve, 1977.

Vlekke, B.H.M. Nusantara a History of Indonesia. The Hague dan Bandung: Van Hoeve, 1943.

Winstedt, R.O. "A History of Malaya", Journal of The Malayan Branch Royal Asiatic Society, Vol. XIII, No. 1, 1935. 